Volume 01 Nomor 01, Desember 2017

\title{
THE LEGAL CONSEQUENCES OF INCOMPLETE BUILDING LICENSE TO THE SALES AND PURCHASE AGREEMENT OF APARTMENTS (CASE STUDY OF MEIKARTA'S INCOMPLETE BUILDING LICENSE)
}

\author{
Sujana Donandi S \\ Faculty Staff at Law Study Program, Universitas Presiden, Cikarang \\ sujana@president.ac.id
}

\begin{abstract}
The construction of Meikarta, a place which is claimed as The New Jakarta on an Approximately 500 acres (ha) land has attracted public attention. There have been 117.797 reservation for apartments unit of Meikarta. However, the rejection from the government due to the incomplete building license of Meikarta has caused 2 main problems regarding the validity of the agreement of the apartment and its legal consequences caused by the incomplete building license. The purpose of this research are to examine the legal validity of sales and purchase agreement of apartment which its constructing license is incomplete and To determine and describe the legal consequences of it. This research will be conducted using normative legal research method. Normative Legal Research Method is a legal research conducted by examining literacy sources or secondary sources.An Agreement of an apartment like Meikarta which its building license incomplete is null and void.The status of an agreement that is null and void brings legal consequences for each parties to restore themselves to the previous position before the agreement was conducted, so that each parties should return back right of other party and vice versa.
\end{abstract}


Volume 01 Nomor 01, Desember 2017

\section{CHAPTER I. INTRODUCTION}

\section{A. Background}

The construction of Meikarta has attracted public attention. Approximately 500 acres (ha) of land has been prepared to build the new city that located in Cikarang, West Java. The marketing is running massively, either through exhibitions, face to face promotion, and even using commercial advertisement in television. Meikarta is not only known by people in west java but also people across Indonesia now.

Sincethe project was officially been published to public, Meikarta began offering their products to consumers.Many consumers have booked apartments unit and paid the booking fee. The latest data by September 2017 showed that 117.797 units apartments of Meikarta have been booked by the Customers. The customers are both from west java regional and out of west java.

In the middle of the incursion of marketing of Meikarta, it was confirmed that Meikarta is not fulfilled the eligibility of its licensing to construct the buildings. The Regional Government of West Java, through the Vice Governor, Dedy Mizwar said that the action of Meikarta is contradictive to the Regional Regulation of West Java No.12 Year 2014 concerning on The Managementof Development and The Development of Metropolitan and Growth Center in West Java.Hence, Dedy Mizwar considers that Meikarta selling products are illegal.The government also prohibits the process of Meikartabuilding construction though there has been no clarity what legal instrument will be used to stop the construction. 
By the rejection from the government due to the incomplete building license of Meikarta, then how is the validity of the agreement between Meikarta and Consumers that already booked 117.797 apartments unit? This problems is certainly interesting to be examined for it is associated with the legal protection for the consumers.By the unfolding of the absence of licensing, Meikarta can be considered as committedto fraud to the public if during the marketing process they informed that Meikarta already obtain the licensing.In addition, If finally failed to build the apartment, then there would be some legal consequences attached to Meikarta as they were default to perform their promise to the consumers.

These questions attracted Author's attention and was the starting point for Author to write this"The Legal Consequences ofIncomplete Building License to The Sales and Purchase Agreement of Apartments"paper. Author would examine the validity of sales and purchase agreement of apartments which its Constructing license is incomplete. After determining the validity, the author would be able to explore its legal consequences.

\section{B. Problem Identification}

Issues that will be discussed in this research are:

1. How is the legal validity of sales and purchase agreement of apartment which its constructing license is incomplete?

2. How isthe legal consequences of the incomplete building license to the saland purchase agreement of an Apartment? 


\section{Objectives}

The Objectives of this research are:

1. To determine and describe the legal validity of sales and purchase agreement of apartment which its constructing license is incomplete.

2. To determine and describe the legal consequences of The Incomplete Constructing License to The sales and purchase Agreement of an Apartment.

\section{Research Utilization}

The utility of this research are:

1. Theoretically, this research will be usefulfor the extension and development of legal knowledge, especially contract law. In addition, this research can improve the scientific writing skiespecially.

2. In practice, this study can be utilized to solve the emerging problems regarding the sales and purchase agreement of apartment which its constructing license is incomplete.

\section{CHAPTER II. LITERATURE REVIEW}

\section{A. The General Review concerning on Sales and Purchase Agreement}

\section{Definition of Agreement}

According to Black Law's Dictionary,an agreement has a wider meaning than a contract. All contract is agreement, but not all agreement is contract. ${ }^{1}$ Until now the term agreement or contract often still be understood

${ }^{1}$ I.G. Rai Widjaja, 2004,Merancang Suatu Kontrak. Contract Drafting. Teori dan Praktek, Bekasi: Kesaint Blanc, page. 12. 
in ambiguous in business practices. Many business actors understand that both terms are different. According to Yudha hernoko, based on the civil law perspective, the term Agreement has equality to the term of Contract. In business practices, The both terms are commonly used in a commercial consensus, such as franchising agreement, leasing agreement, cooperation agreement,collaboration, and constructing agreement. $^{2}$

Yudha's opinion are denied by some scholars. The term of contract according to subekti has a narrower meaning because it is addressed to agreement or concurrence made in writing. ${ }^{3}$ Steven 1.Emanuel asserted also that :

"A contract is an agreement that the law will enforce in some way. A contract must contain at least one promise, i.e. a commitment to do something in the future"

It means that contract is a an agreement which law will enforce it in various ways. A contract at least must load one promise, a commitment to conduct something in the future. ${ }^{4}$

The definition of agreement according to Indonesian Civil Code in article 1313 said that agreementis a deed by which one person or more bind themselves over one other person or more. Regarding the term "agreement", Peter Mahmud Marzuki also provides his point of view.Peter explained that the use of a term of contract or agreement in civil code

\footnotetext{
${ }^{2}$ Agus Yudho Hernoko, 2008, Hukum Perjanjian: Asas Proporsionalitas dalam Kontrak Komersial, Yogyakarta: LaksBang Mediatama dan Kantor Hufron dan Hans Simalea, page. 13.

${ }^{3}$ R. Subekti, 1996, Hukum Perjanjian, Jakarta : Intermasa, page. 1.

${ }^{44}$ Steven Emanuel, 2004, Contracts, New York : Aspen Publisher A Wolters Kluwer Company, page. 1.
} 
which was influenced by the Europe-Continental Legal System could be compared to what contract or agreement in Anglo-Saxon Legal System. ${ }^{5}$

Furthermore, Peter explained that Civil Code in Book III concerning on verbintennissenrecht (law of engagements) sets up onovereenkomst that if translated into indonesian language means perjanjian (agreement). Term of "Contract" is a translation of contract in english.In the europe-continental legal concept, the deployment of the arrangement of agreement in Civil Code book III concerning on legal engagements indicates that the agreements are related to the wealth issues (vermogen), similar to contract in the concept of anglo-saxon law concept relating to the business. ${ }^{6}$

Mariam Darus Badzulrahman defined a contract or agreement as legal action occuring engagement, namely the legal relation that happened between two or more people, addressed in in the field of wealth where one of the party is entitled to performance and other parties obliged to perform. ${ }^{7}$

Wiejono prodjodikoro also provided his opinion on the meaning of contract that it is alegal relationship concerning on the wealth between two parties in which one hand promise to do something or did not do something, and the other is entitled to demand it. ${ }^{8}$

Based on the above opinions, an agreement is mainly a legal relation that happened between two or more persons, addressed in the field

${ }^{5}$ Peter Mahmud Marzuki, 2003, Batas-Batas Kebebasan berkontrak, Yuridika, page. 195-196.

${ }^{6}$ Ibid

${ }^{7}$ Mariam Darus Badzulrahman, 1980, Kontrak Baku (Standar Perkembangannya di Indonesia), Medan: Universitas Sumatera Utara, page. 3

${ }^{8}$ R. Wirjono Prodjodikoro, 1991, HUkum Perdata tentang Persetujuan Tertentu, Bandung: Penerbit Sumur, page. 1. 
of wealth that demands performance from each parties who bind themselves in agreement. Contract as a form of written agreement is very important in a bond as the contract is a guide in fulfilling each parties obligation. In addition, contract is a strong evidence before the court in the settlement of event of default.

\section{Conditions of a Valid Agreement}

The validity ofan agreement according to Article 1320 Indonesian Civil Code required four conditions:

a. consensus(toesteming/approval) of both parties;

b. Capacity

c. Certain Object;and

d. Lawful purpose (geoorloofde oorzaak)

There are several conditions to contract that generally accepted but is organized out of the civil code governance, as follow:

a. a contract mustbe undertaken in good faith;

b. contract shall not contradict to conventions;

c. a contract to be done based on the principles of propriety;

d. a contract shall not break the public interest.

\section{Sales and Purchase Agreement}

According to Article 1457, Indonesian Civil Code, sales and purchase agreementis a consensus by which one of the parties bind themselves to deliver an object and the other side to pay the promising price.Trading is reciprocal.It means each party bear a performance 
foranother party and performance from the opposite side is the form of reciprocal for the performance conducted by the other party.

The sales and purchaseagreement considered happened for the two sides instantly after the parties reach the consent on the object of trade and price, although the object is not given yet and the agreed price have not yet been paid.Goods and the price is the basis of the existence of sales and purchase agreement.

\section{Performance and Event of Default}

A consequence occured from an agreement is that parties obtain some obligationthey must fulfill. In an agreement, both parties were asked to do or not do something. This obligation was also known as performance. The term "performance" in an agreement is the conduction of the contents of the contract that has been made by the parties in the agreement.An agreement has three meaning of performance, namely: ${ }^{9}$

a. handing over of a goods;

b. performing an action;

c. not perform an action.

Someone who fail to meet the performance in a an agreement will be considered as committed to Even of Default (wanprestasi). Default (nonfulfillment, breach of contract, or injured promise) according to Munir Fuady is the unsettled performance or obligation as it should be charged by contract to the parties mentioned in an agreement, or that is the curving of

\footnotetext{
${ }^{9}$ Syahrin Naihasy, Hukum Bisnis (Business Law), Mida Pustaka, Yogyakarta, 2005, page. 46.
} 
the implementation of the agreement, thus rises to losses caused by faulty of one of the parties. ${ }^{10}$

A debitor or party who undertake an obligation to be implemented in an agreement, can be expressed being default in four kind of situations, namely: ${ }^{11}$

a. not doing the performance at all;

b. implement the performance, but not as well as it should be;

c. implement the performance, but late;

d. Do the forbidden things as it is governed in an agreement.

According to both explanation, Author infer that basically performace occurs as a result of the existence of agreement between parties who bound themselves in an agreement. When there were part who do not perform, then the party will be considered in default.Default of one party might cause losses for other party.

\section{Remedies}

Understanding of losses (schade according to Civil Code) is a real losses (feitelijkschade) that may be suspected or estimated by the parties at the time they made an agreement, which arises as a result of default.The total losses is determined based on a comparison between the worth of the wealth after the Event of Defaultand the worth of the wealth if the default had never been happened. ${ }^{12}$

\footnotetext{
${ }^{10}$ Munir Fuady, 2001, Hukum Kontrak (Dari Sudut Pandang Hukum Bisnis), Bandung: Citra Aditya Bakti, page. 87.

${ }^{11}$ Muhammad Syaifuddin, 2012, Hukum Kontrak, Bandung: Mandar Maju, page. 338.

${ }^{12}$ Ibid.
} 
In doctrinal, according to Niewenhuis as it was quoted by Urwahid tried to give definition on losses, that it is the reduced of the wealth of one party (the party being disadvantaged), caused by action (both conducting or neglecting) things against the norms (in this case: Event of Default) by other parties (debtor).Losses formed by the comparison between the factual situation on how it is the reality of the wealth as the consequences of a violation to norms (in this case: Event of Default) with hypothesis regarding how woud the situation be if the violation of norms never happened (in this case: Event of Default). Losses are consisting of two components, such as:

1 .The apparent loss suffered ( damnum emergens ), includes: the cost and losses;

2 .Profits that are not obtained (lucrum cessans), in the form of interest. ${ }^{13}$

Pertaining to remedies due to Event of Default, Mariam Darus Badrulzaman stated that the form of remedies arising as a result of default that commonly used is money, because according to the Civil Law Expert and jurisprudence, money is the most practical and at least potential to cause the difference in resolving disputes. In addition to money, the form of other compensation, namely the restoration to the previous situation and banned for the repetition, as if it was not complied, can be reinforced by forced money. So, forced money is not a form of compensation. ${ }^{14}$

Through above explanation, Author can conclude that remedies is a form of responsibility for party who is default and cause lossesto the

\footnotetext{
${ }^{13}$ Purwahid Patik, 1994, Dasar-Dasar Hukum Perikatan, Bandung: Mandar Maju, page. 14.

${ }^{14}$ Mariam Darus Badrulzaman, Op. Cit, page. 20.
} 
other hand. Remedies awarded in accordance to the amount of losses caused by the event of default and also the tort that causes losses to the other party.

\section{B. The General ReviewConcerning OnApartment}

Article 1 Paragraph (1) of Law Number 20 Year 2011 concerning on Apartment hereinafter referred to The Law of Apartment said that apartment is a floored building which is built in an environment which is divided into parts, constructed by function, both in a horizontal direction or vertical and that each of the units can be owned and used separately, especially to place dwelling that furnished with a joint part, joint object, and joint land.

The law of apartment devided apartment into four categories: ${ }^{15}$

1. Common Apartment, that is an apartment organized to comply the need of housing for the poor family;

2. Special Apartment, is apartment made to meet special needs;

3. Apartment of State, is apartmen owned by the state and serves as the residence, training facility, and supporting facility of officials task and/or civil servants; and

4. Commercial Apartment, is apartment that made to earn profit.

The construction of the apartment by certain parties must be based onthe classified purposes above. Those who construct the apartment, also known as the perpetrator of the construction of the apartment, namely every person and/or the Government that do the construction of housing

\footnotetext{
${ }^{15}$ Read Article 1 Number 7-10 Law of Apartment
} 
and settlements. ${ }^{16}$ Each persons are individual and legal entities. ${ }^{17}$ In the case of meikarta, Lippo Group serves as the perpetrator of the construction of the apartments. Lippo is a business entitywith legal entity status known as Limited Liability Company (Perseroan Terbatas (PT)).

\section{The completeness of The Building License of Apartments}

In doing the construction of apartments, the developer should comply administrative requirement including: ${ }^{18}$

1. The status of land rights; and

2. Building Constructing License (Izin Mendirikan Bangunan).

The status of the land right according to Indonesian Basic Regulation on Land (Undang-Undang Pokok Agraria/UUPA) classified the rights into some classification:

1. Hak Milik, is the right of hereditary, the strongest and the most complete right of a land owner could have.(article 20);

2. Hak Guna Usaha, is the right to work on a land controlled by the state directly for a certain period of time for doing farming enterprise, fisheries or animal husbandry. (article 28)

3. Hak pakai, according to the provisions of article 41 UUPA, Hak Pakai is a right that allow to use and or picked up the result of land that controlled by the state or land belonging to someone else directly, which given powers and duties that are determined in the giving right resolution by the official authorized or in agreement with the owner of

${ }^{16}$ Article 1 Number (15)

${ }^{17}$ Article 1 number (16)

${ }^{18}$ Article 28 Law of Apartment 
the land, which the agreement is not a leasing agreement or agreement on the managing of land, everything as long as it is not contrary to the spirit and provisions of UUPA.

4. Hak Sewa, is the right which provide powers to use land belonging to the other party that followed by an obligation to pay the lease in every certain time. (article 44 and 45 uupa)

5. Hak Membuka Tanah dan memungut hasil hutan, is a right given to some party to open land and to collect forestry products that can be acquired only by indonesian citizens and regulated with a government regulation.Using this right legally does not occur the user obtain the right belonging over the land.

Meanwhile, Building Constructing License according to Article 1 Number 6 Government Regulation no 36 Year 2005 states that IMB is licensing rendered by the district/city governments to the building owner to establish anew building, renovating, extending, reducing, and/or tending the building in accordance to the administrative requirements and technical requirements prevailing.

IMB is one of the mandatory requirements obliged in implementing the establishment of a building. Licensing application of a building proposed by the owner of the building to The Local government in line with the regulation and procedureof application where the building is going to be established.

The developer should build be the apartment and its environment in accordance to the planned function and its using. The Planned functions and its using as referred to Paragraph (1) should obtainthe permission from 
the local principle or major. Entreaty of licensing shall be conducted by attaching terms as follows:

1. Certificate of land rights;

2. A District Letter Plan;

3. The Drawing footprint of land; and

4. The Drawing architecture of plan containing the blueprint, glimpse of look of the apartment showing the limitationof the apartment both vertically and horizontally;

5. The Drawing of the plan structure and reckoning;

6. The Drawing of a plan showing by clear the joint part, objects, and land;

7. The Drawing of the general utility and installation along with the equipment.

The developer after obtaining the license shall be obliged to request the endorsements from the regional government about the explanation on the clear boundary of the apartment, the joint part,object, and land along with the explanation of the NPP. It is applied for every developer. In the case of Meikarta, Lippo Group as the developer must meet the requirements over the licensing as other developer do.

Article 33 of Law of Apartment further explained that further provisions regarding permit application plan functions and the use of apartment will be regulated further in a regional regulation.This requirement shows that every possessor of the construction of apartments have to follow the licensing rule that applied in the province where the apartment will be build. In the case of Meikarta, the location in cikarang 
which is a part of West Java province.Hence, The buildingof Meikarta must meet the requirements of apartment building license in west java.

\section{CHAPTER III. RESEARCH METHODOLY}

\section{A. Type of Research}

This research will be conducted using normative legal research method. Normative Legal Research Method is a legal research conducted by examining literacy sources or secondarysources. ${ }^{19}$ Normative Legal Reserach also known as Doctrinal Research, a research which its object of research are documents of legislation and literacy material. ${ }^{20}$

This study will exercisethe validity of a sales and purchase agreement of apartment which its building license is incomplete by using norms or related regulations as instruments to try. Besides, this research would also using opinions of experts that are provided in literarure and other written sources.

\section{B. Research Approach}

This research using statute approcah. This approach conducting by analyzing all the laws and regulations related to the issue of the law that is being discussed. ${ }^{21}$ This study will analyse the legislation as well as related

\footnotetext{
${ }^{19}$ Soerjono Soekanto dan Sri Mamudji, 2003, Penelitian Hukum Normatif: Suatu Tinjauan Singkat, Jakarta: PT. RajaGrafindo Persada, page. 13.

${ }^{20}$ Soejono dan H. Abdurahman, 2003, Metode Penelitian Hukum, Jakarta: Rineka Cipta: page. 56.

${ }^{21}$ Peter Mahmud Marzuki, 2011, Penelitian Hukum, cetakan ke-11, Jakarta: Kencana, page. 93.
} 
regulations related to the validity of the trading agrrement of an apartment which its constructing license is incomplete.

\section{C.Sources of Research}

Sources used in this research are resources that is needed incarrying normative research, namely: ${ }^{22}$

\section{Primary Legal Sources}

Primarly legal sources is an autoritative which means undertaking authority. Primary Legal Sources consisting of legislation, official notes, or treatise in the legislation drafting. Beside legislation, the other authorized primary legal sources is jurisprudence. jurisprudence is the concretationof legislation. Jurisprudence is actually a law in action.

2. Secondary Legal Sources, is all publication regarding law which is not an official documents. They are Publications of the law including text books, law dictionaries, law journals, and comments on jurisprudence.Those writings of law containing the development or actual issues of a certain area of law.

Moreover, for the interest of the research, a researcher can refers to some other non-legal sources. The non-legal sources could be political, economic, sociology, and philosophical books, or non-legal research and journals as long as the resources has correlation with the research topic.

\footnotetext{
${ }^{22}$ Ibid, page 141-143.
} 
Volume 01 Nomor 01, Desember 2017

\section{CHAPTER IV. DISCUSSION}

\section{A. The Legal Validity of Sales and Purchase Agreement of an Apartment which Its Constructing Building License Is Incomplete}

Sale and Purchase agreements in this research are including agreement with the payment on the transaction and the binding of The Sales and Purchase agreement which is still in the process of instalments until the instalments is paid To occur The Sales and Purchase agreement. The binding agreement is basically an agreement as well . Therefore, the agreement which is referred in this research are belong to the agreement both the one which has been paid and also the one which is in the process of instalment.

Legal discussions regarding the validity of an agreement is dependent on the fulfillment of the legal condition in the agreement .This is applied for all agreement that is subject to the law of the country. The Sales and Purchase agreement of Meikarta is a Sales and Purchase Agreement which is subject to indonesian law.Hence, The Sales and Purchase Agreement of Meikarta must meet the legal condition of an agreement as stipulated in Article 1320 Indonesian Civil Code, as follows:

a. consensus (toesteming/approval) of both parties;

b. Capacity

c. Certain Object;and

d. Lawful purpose (geoorloofde oorzaak)

The Sales and Purchase Agreement of Meikarta involves two parties namely the the seller and buyer . Liipo Group as the developer of 
the apartment apartments stands as a seller. Meanwhile, the buyers can derived of several types of buyers, ranging from individuals, business entities without legal entity, as well as a legal entity. If individuals, then the indivisuals must meet the requirements to be considered capable in performing an agreement .

The Sales and Purchase agreement of Meikarta will be considered considered the consensual condition when parties consciously join themselve to the agreement. Consensus should also fulfill the condition that neither side is pressed or threatened to agree on The Sales and Purchase Agreement. Consensus should alse be undertaken in good faith. By the presence of awareness to bind self, there shall be no compulsion, and the existence of the good faith, A Sales and Purchase agreement of Meikarta already fulfilled the first legal condition of agreement, consent of parties .

The second condition is Capability. A natural person is qualified to conduct an agreement if he is minimum 21 years old or under 21 years but married. In addition, someone has to be mentally health, not being under guardianship, and are allowed by law to make an agreement. For the buyers, as long as they fulfill the criteria, then the agreement qualify the second condition.

The third requirement is a specific/certain object. As long as the object of the agreement is detail and determinable, then the agreement is recognized by the law.By the presence of the detail of the object which in this case is apartment, such as the location, apartment specification, and other information of the object are clearly provided in the agreement, so that there will be no multiinterpretation on the object of the agreement, so 
the Sales and Purchase agreement of Meikarta is considered fulfilling the third legal condition.

The fourth requirement of the validity of an agreement that is a lawfull purpose. A lawfull purpose requires that the cause of the agreement is not prohibited by the law.In other words, there is no law ban this agreement to be conducted.This is clearly regulated in article 1337 Civil Code:

"a purpose is forbidden if the purpose is prohibited by the law or if is contrary to the decency or public order."

What about Meikarta then?The Head of Infrastructure and Regional Development Planning Distric Bekasi, EY Taupik said that at the beginning the total provided area for Meikarta was 360 ha, and Meikarta requested the building license for of 140 ha, only 84 ha already proven, not 500 ha as what Meikarta has had advertised.He added that not the entire land is accordance with the regional landscaping plan of Bekasi, so that the license for the unappropriate land still be suspended.

If that was the case, then do a sales and Purchase agreement of apartment which its building license is incomplete like Meikarta be considered not fulfilling the fourth legal condition of an agreement? In answering this problem we can refer to Article 33 of Law of Apartment that that required shows every possessor of the construction of apartments have to follow the licensing rule that applied in the province where the apartment will be build. In the case of Meikarta, the location in cikarang which is a part of West Java province. 
Local governments have confirmed that some part Meikarta's land have not meet the requirement of establishment. In the sale and purchase agreement of Meikarta, it will be considered qualifying the fourth legal condition if the apartment does not contain things that forbidden by the law.In this case, 84 ha of land of Meikarta have required the building license. However, there are still some portions of which is not fulfill the building construction.

Based on the conditions above, then Meikarta actually have fulfilledthe building license for some sort of land. Nevertheless, what about Meikarta status that does not earn license for the rest of the land? Do the licensing requirements must be met during the agreement or could it be after the agreement.In other words, what if Lippo after the agreement held, be capable of being qualified to build the apartment ? Will the agreement be legitimate? During the requirement is not complete but the agreement already existed, what is the status of the sales and purchase agreement of the apartment? Will it be invalid?

According to the author, the nature of the fulfillment of legal condition of agreement is "real time". It means that those condition must be fulfilled when the agreement was done. If the building license isnot fulfilled at the time when the agreement was held, then the agreement will be considered null and void even though the law does not forbid the sale of apartments which its building license is incomplete, but the law prohibits the construction of apartment without license.In other words, by making the sales and purchase agreement, the parties willing to create a right upon 
an object in the jurisdiction of Indonesia which shoul comply the legality requirement in Indonesia.

If the construction of Meikarta done on a land that is not permitted by the authorized, so the construction is prohibited by law. When the parties agreed to make a sales and purchase agreement on apartment located on a land without license, so the agreement is null and void because the purpose of the agreement is contrary to the law. The parties will be considered not abide the law because agreed to an object that its existence is not recognized by law.Hence, the Sales and Purchase Agreement of apartment of Meikarta on a land that is not authorized led legal consequences that the agreement is null and void.

As results, to decide which agreement is fulfilling the lawfull purpose can be determined by the location of the apartments unit. If the apartment is located on the land which its building license is complete, then the agreement is fulfilling the lawfull purpose condition. On the other hand, if the object of the sales and purchase agreement is located on a land without license, then the agreement is null and void.

So, the validity of the sales and purchase agreement of Meikarta can be analyzed by the fulfillment of the legal conditions of the agreement. If the four legal condition of the agreement is fulfilled, then the agreement is valid. However, if the first and second condition as the subjective condition of agreement has not been fulfilled in the sales and purchase agreement of Meikarta, then the agreement can be cancelled. This situation means that one party can ask to cancel this agreement to the court. On the other hand, if the parties want to continue the agreement then the 
agreement can be proceed as long as the agreement fulfill the third and fourth condition.

Meanwhile, when the agreement is ineligible to the third and fourth condition then the agreement is null and void. Law will consider that the agreement never exist. So, based on the explanation, author can conclude that In Meikarta case, there are two status of the validity of the agreement. First, the agreement is valid if the object licensed land. Second, the agreement is null and void if it is build on a land which its building license is incomplete.

\section{B. Legal Consequences of The Sales and Purchase Agreement Which Its Building Licenseis Incomplete}

At the previous discussion, It hasbeen explained that there are some part of Meikarta's land which already obtain the building license. Meanwhile, some other is not yet.The difference in these two parts status regarding the license will effect the legal consequences differently.

For the land that earn the building license, the legal consequences emerge to the Sales and Purchase agreement. For a Sales and Purchase Agreement, the legal consequences for the seller is the seller must deliver the goods or object as has been agreed to the seller. For that performance, so the seller have a right to receive payment for the goods that was been delivered.On the other hand, the agreement for the buyer cause the buyer should pay the object to the seller and the buyer is rightful to receive the good from the seller. 
In Meikarta case, Lippo group as the seller is entitled to receive payments from buyers.Besides the emergence of due to legal for lippo to receive the right in the form of the payment, Lippo is also legally obligated to provide and turn over the units of apartment as has been agreed. Meanwhile, buyers of Meikarta are mandated to pay the price of the building and they are rightfull to receive the units from Lippo.

On the other hand, Meikarta's agreements that does not fulfil the objective conditions are null and void by the law .This is also applied to meikarta agreement which has no license to operate.That agreement is null and void because the agreement $\mathrm{s}$ are prohibited by law and has no lawfull purpose. By this situation, then each parties should be restored to the previous position before the agreement was conducted, so that each parties should return back right of other party and vice versa.

\section{CHAPTER V. CONCLUSION}

Based on the discussion, author can conclude two main ide as follows:

1. An Agreement of an apartment like Meikarta which its building license incomplete is null and void.

2. The status of agreement that is null and void brings legal consequencesfor each parties to restore to the previous position before the agreement was conducted, so that each parties should return back right of other party and vice versa. 


\section{BIBLIOGRAPHY}

\section{A. BOOKS}

Abdurahman , Soejono dan H. 2003. Metode Penelitian Hukum. Jakarta: Rineka Cipta.

Badzulrahman , Mariam Darus. 1980. Kontrak Baku (Standar Perkembangannya di Indonesia). Medan: Universitas Sumatera Utara.

Emanuel, Steven. 2004. Contracts. New York : Aspen Publisher A Wolters Kluwer Company.

Fuady, Munir. 2001. Hukum Kontrak (Dari Sudut Pandang Hukum Bisnis. Bandung: Citra Aditya Bakti.

Hernoko, Agus Yudho. 2008. Hukum Perjanjian: Asas Proporsionalitas dalam Kontrak Komersial, Yogyakarta: LaksBang Mediatama dan Kantor Hufron dan Hans Simalea.

Marzuki, Peter Mahmud. 2011.Penelitian Hukum, cetakan ke-11. Jakarta: Kencana.

Naihasy,Syahrin. 2005.Hukum Bisnis (Business Law). Mida Pustaka. Yogyaka rta.

Patik, Purwahid. 1994.Dasar-Dasar Hukum Perikatan. Bandung: Mandar Maju.

Prodjodikoro, R. Wirjono. 1991. HUkum Perdata tentang Persetujuan Tertentu. Bandung: Penerbit Sumur.

Soekanto, Soerjono dan Sri Mamudji. 2003. Penelitian Hukum Normatif: Suatu Tinjauan Singkat. Jakarta: PT. RajaGrafindo Persada. 
Subekti, R. 1996. Hukum Perjanjian. Jakarta : Intermasa.

Syaifuddin, Muhammad. 2012. Hukum Kontrak. Bandung: Mandar Maju.

Widjaja, I.G. Rai. 2004. Merancang Suatu Kontrak. Contract Drafting. Teori dan Praktek. Bekasi: Kesaint Blanc.

\section{B. LEGISLATION}

Indonesian Civil Code

Regional Regulation of West Java No.12 Year 2014 concerning on The Management of Development and The Development of Metropolitan and Growth Center in West Java 